\title{
Photosynthetic Daily Light Integral Impacts Growth and Flowering of Several Kalanchoe Species
}

\author{
Christopher J. Currey and John E. Erwin ${ }^{1,2}$
}

ADDITIONAL INDEX WORDS. dry weight gain, irradiance response, new crops, total flower number

Summary. Our objective in this study was to identify the effects of the photosynthetic daily light integral (DLI) on growth and flowering of six kalanchoe (Kalanchoe) species: Kalanchoe glaucescens, christmas tree plant (K. laciniata), chandelier plant ( $K$. manginii), shovel leaf kalanchoe ( $K$. nyikae), common kalanchoe or nentabos (K. rotundifolia), and velvet leaf kalanchoe (K. velutina). Plants were grown under an 8-hour photoperiod with a DLI of 4.3, 8.6, or 17.2 $\mathrm{mol} \cdot \mathrm{m}^{-2} \cdot \mathrm{d}^{-1}$. Node numbers below the terminal inflorescence on $K$. glaucescens, $K$. manginii, K. nyikae, and $K$. rotundifolia decreased as the DLI increased, whereas node numbers of $K$. laciniata and $K$. velutina were unaffected by DLI. Time to first open flower of $K$. glaucescens, $K$. nyikae, and $K$. rotundifolia was unaffected by the DLI, whereas increasing the DLI from 4.3 to $17.2 \mathrm{~mol} \cdot \mathrm{m}^{-2} \cdot \mathrm{d}^{-1}$ reduced the time to first open flower of $K$. laciniata, $K$. manginii, and $K$. velutina. Total flowers for all species increased as the DLI exceeded $4.3 \mathrm{~mol} \cdot \mathrm{m}^{-2} \cdot \mathrm{d}^{-1}$. Shoot heights of $K$. glaucescens and $K$. rotundifolia increased as the DLI increased from 4.3 to 8.6 $\mathrm{mol} \cdot \mathrm{m}^{-2} \cdot \mathrm{d}^{-1}$, whereas shoot height of $K$. nyikae decreased as the DLI increased from 4.3 to $17.2 \mathrm{~mol} \cdot \mathrm{m}^{-2} \cdot \mathrm{d}^{-1}$; shoot heights of $K$. laciniata, $K$. manginii and $K$. velutina were unaffected by DLI. Dry weight gain increased for all species as the DLI exceeded $4.3 \mathrm{~mol} \cdot \mathrm{m}^{-2} \cdot \mathrm{d}^{-1}$.

$\mathrm{R}$ ecommendations for light during commercial greenhouse crop production is often reported in $\mu \mathrm{mol} \cdot \mathrm{m}^{-2} \cdot \mathrm{s}^{-1}$, an instantaneous measurement of light intensity (Dole and Wilkins, 2005; Hamrick, 2003). However, light intensity varies greatly within a single day and over the course of a growing season (Lambers et al., 2008; Larcher, 2003). Therefore, the integrated photosynthetic DLI expressed in moles per day is a more accurate description of light during crop production as it is the cumulative light received over the course of a day (Fausey et al., 2005).

Commercial producers of potted and bedding plants aim to decrease total production time and maximize flower number and biomass of flowering plants. The DLI during crop production has been reported to affect these traits. For example, as the DLI increases, the time to flowering and node number below the first flower decrease, whereas flower number and dry weight gain increase for many bedding plant species (Faust et al., 2005; Mattson and Erwin, 2005; Warner and Erwin, 2005). Similar results have been reported for potted flowering crop species including cyclamen [Cyclamen persicum (Oh et al., 2009)], hibiscus [Hibiscus spp. (Warner and Erwin, 2003)], and kalanchoe species (Carvalho et al., 2006; Zimmer, 1985).

The majority of potted and bedding plant production in the United States occurs in the fall, winter, and early spring (Garland et al., 2010). This is the time of year when ambient outdoor DLIs are at seasonally low levels (Korczynski et al., 2002). Inside the greenhouse, DLI is further reduced because of greenhouse glazing and interior structures (Hanan,
1998). During these periods with low DLIs inside the greenhouse, commercial producers must decide whether to provide supplemental irradiance to produce high-quality finished plants. However, species vary in their DLI requirement with respect to crop quality (Faust, 2003). Therefore, it is important to identify how irradiance during production affects growth, development, and ornamental quality when evaluating germplasm for introduction as a new floriculture crop (Roh and Lawson, 1998; Wilkins and Erwin, 1998).

The genus Kalanchoe contains 139 species (Descoings, 2005). We identified several kalanchoe species with potential as new ornamental potted and/or bedding plants: K. glaucescens 'Freeling's Sensation', K. manginii, K. laciniata, $K$. nyikae, $K$. rotundifolia, and $K$. velutina (Currey, 2009). These species have ornamental potential on the basis of unique plant form, foliage, flowers, and/or inflorescences. The objective of our research was to identify the effect of the DLI on growth and flowering of six kalanchoe species with desirable ornamental characteristics.

\section{Materials and methods}

Propagation and propagule CULTURE. Rooted and unrooted cuttings of $K$. glaucescens 'Freeling's Sensation', $K$. laciniata, $K$. manginii, $K$. nyikae, K. rotundifolia, and K. velutina were obtained from two different firms (Altman Plants, Vista, CA, and Glasshouse Works, Stewart, $\mathrm{OH}$ ) and used to start stock plants. Vegetative stock plants were maintained in a greenhouse with $22 \pm 1{ }^{\circ} \mathrm{C}$ and $18 \pm 1{ }^{\circ} \mathrm{C}$ day and night air temperature set points, respectively, under ambient light conditions (St. Paul, $\mathrm{MN}$, lat. $45^{\circ} \mathrm{N}$ ) supplemented with $75 \mu \mathrm{mol} \cdot \mathrm{m}^{-2} \cdot \mathrm{s}^{-1}$ photosynthetic photon flux from high-pressure sodium lamps when ambient light intensity was $<200 \mu \mathrm{mol} \cdot \mathrm{m}^{-2} \cdot \mathrm{s}^{-1}$ from 0700 to 0100 HR (18-h photoperiod). Plants were irrigated with tap water when substrate appeared dry and fertilized weekly with

Department of Horticultural Science, University of Minnesota, 1970 Folwell Avenue, Saint Paul, MN 55108-6007

Mention of trade names in this publication does not imply endorsement by the Minnesota Agriculture Experiment Station of products named, nor criticisms of similar products not named.

${ }^{1}$ Professor

${ }^{2}$ Corresponding author. E-mail: erwin001@umn.edu.

\begin{tabular}{clll}
\hline $\begin{array}{l}\text { Units } \\
\text { To convert U.S. to SI, } \\
\text { multiply by }\end{array}$ & U.S. unit & SI unit & $\begin{array}{l}\text { To convert SI to U.S., } \\
\text { multiply by }\end{array}$ \\
\hline 29.5735 & $\mathrm{fl} \mathrm{oz}$ & $\mathrm{mL}$ & 0.0338 \\
2.54 & inch(es $)$ & $\mathrm{cm}$ & 0.3937 \\
16.3871 & inch & $\mathrm{cm}^{3}$ & 0.0610 \\
28,350 & $\mathrm{Oz}$ & $\mathrm{mg}$ & $3.5274 \times 10^{-5}$ \\
1 & $\mathrm{ppm}$ & $\mathrm{mg} \cdot \mathrm{L}^{-1}$ & 1 \\
$\left({ }^{\circ} \mathrm{F}-32\right) \div 1.8$ & ${ }^{\circ} \mathrm{F}$ & ${ }^{\circ} \mathrm{C}$ & $\left(1.8 \times{ }^{\circ} \mathrm{C}\right)+32$
\end{tabular}


tap water supplemented with watersoluble fertilizer (Excel 15N-2.2P12.5K Cal-Mag; Scotts, Marysville, $\mathrm{OH})$ to provide 200 ppm nitrogen during each fertilization. The $\mathrm{pH}$ and alkalinity of the tap water was 7.7 and $55 \mathrm{mg} \cdot \mathrm{L}^{-1}$, respectively.

On 26 Jan. 2009, 15 terminal shoot-tip cuttings of each species with about three to five nodes, depending on the species, were harvested. The lowest set of leaves was removed from the cutting, and the cuttings were dipped in talc powder containing $1000 \mathrm{ppm}$ indole-3-butyric acid (Hormodin 1; $\mathrm{OHP}$, Mainland, PA) to promote rooting. The cuttings were then placed in soilless high-porosity substrate composed of pine bark, Canadian sphagnum peat, vermiculite, and coarse perlite (SB500; Sun Gro Horticulture, Bellevue, WA) in 128-cell plug trays (25-mL individual cell volume). Air temperature and light were as described earlier, with a substrate temperature set point of $21{ }^{\circ} \mathrm{C}$ maintained with bottom-heat mats placed beneath the trays. The cuttings were hand-misted daily and irrigated to maintain moist substrate. After l week, the cuttings were irrigated with tap water and fertilized once weekly as previously described.

After 4 weeks of rooting, the cuttings were transplanted into square plastic pots with 4 inch sides $\left(32.8\right.$ inch $^{3}$ volume) filled with a high-porosity substrate (SB500). The pots were then placed in the same environment in which they were rooted without bottom heat or daily misting. The plants were irrigated with tap water and fertilized once weekly as previously described.

DLI TREATMENTS. After 2 weeks, the plants were divided and five plants of each species were placed in one of three growth chambers (GCW-15; EGC, Chagrin Falls, OH). Growth chambers had light intensities of 150 , 300 , or $600 \mu \mathrm{mol} \cdot \mathrm{m}^{-2} \cdot \mathrm{s}^{-1}$ [as measured with a quantum sensor (LI-COR Biosciences, Lincoln, NE)] provided by fluorescent (75\% of total wattage) and incandescent lamps (25\% of total wattage) from 0800 to $1600 \mathrm{HR}$ (8-h photoperiod), resulting in DLIs of $4.3,8.6$, or $17.3 \mathrm{~mol} \cdot \mathrm{m}^{-2} \cdot \mathrm{d}^{-1}$, respectively. The DLI was calculated as described by Garland et al., (2010). Air temperature was adjusted to maintain day $(8 \mathrm{~h})$ and night $(16 \mathrm{~h})$ plant temperatures of 22 and $18^{\circ} \mathrm{C}$, respectively. The plant temperature was measured on the newest fully unfolded leaf pair from five plants of each species in each chamber using an infrared thermometer (Westward 1EZ22A Infrared Thermometer; Grainger Global Sourcing, Lake Forest, IL). There were no significant differences in leaf temperature between species $\left(21.9-22.6^{\circ} \mathrm{C}\right.$ ) across growth chambers $\left(22.1-22.4^{\circ} \mathrm{C}\right)$. Light intensity and air temperature were continuously adjusted to maintain consistent environments throughout the experiment. The plants were irrigated, as needed, with tap water and fertilized once weekly as previously described.

Data collection. Data recorded on the first flowering shoot for each plant included date of first fully opened flower, node number below the terminal inflorescence, total flower number, and shoot height from the base of the shoot to the top of the inflorescence. The shoot was excised and dry weights were recorded after drying in a $70{ }^{\circ} \mathrm{C}$ oven for $5 \mathrm{~d}$. Time to first open flower was calculated by subtracting the date of placement into treatments from the date of first open flower. Dry weight gain was obtained by dividing the shoot dry weight by time to first open flower.

EXPERIMENTAL DESIGN AND STATISTICAL ANALYSIS. The experiment was organized in a randomized complete block design in a factorial arrangement with five samples (plants) per DLI treatment per species. Factors were species (six levels) and DLI (three levels). The experiment was replicated twice for a total of three replications over time. Analyses of variance and mean separation by Tukey's honestly significant difference test at $P \leq 0.05$

Table 1. Effect of daily light integral (DLI) on node number below the terminal inflorescence on six kalanchoe species.

\begin{tabular}{lccr}
\hline & \multicolumn{3}{c}{ Nodes (no.) } \\
\cline { 2 - 4 } Species & \multicolumn{3}{c}{ DLI $\left(\mathbf{m o l} \cdot \mathbf{m}^{-\mathbf{2}} \cdot \mathbf{d}^{\mathbf{- 1}}\right)$} \\
\cline { 2 - 4 } Kalanchoe glaucescens & $7.5 \mathrm{~b}^{\mathrm{z}} \mathrm{A}^{\mathrm{y}}$ & $\mathbf{8 . 6}$ & $\mathbf{1 7 . 2}$ \\
K. laciniata & $8.7 \mathrm{aA}$ & $8.8 \mathrm{abBC}$ & $6.4 \mathrm{aB}$ \\
K. manginii & $6.4 \mathrm{bA}$ & $4.8 \mathrm{aA}$ & $7.8 \mathrm{aC}$ \\
K. nyikae & $8.7 \mathrm{bA}$ & $7.3 \mathrm{aC}$ & $4.6 \mathrm{aA}$ \\
K. rotundifolia & $7.4 \mathrm{bA}$ & $6.5 \mathrm{aB}$ & $7.5 \mathrm{aC}$ \\
K. velutina & $6.5 \mathrm{aA}$ & $6.2 \mathrm{aB}$ & $6.4 \mathrm{aB}$ \\
Species (S) & $* * *$ & & $6.5 \mathrm{aB}$ \\
DLI $(\mathrm{D})$ & $* * *$ & & \\
S $\times$ D & $* *$ & & \\
\hline
\end{tabular}

${ }^{2}$ Lowercase letters indicate mean separation within a species across DLIs by Tukey's honestly significant difference (HSD) test at $P \leq 0.05$

y Uppercase letters indicate mean separation within a DLI across species by Tukey's HSD at $P=0.05$. $* *, * * *$ Significant at $P \leq 0.1$ or 0.001 , respectively. were performed on all data using SPSS (version 16.0; SPSS, Chicago, IL).

\section{Results}

The species and DLI interacted to affect the node number below the terminal inflorescence (Table 1). As the DLI increased from 4.3 to 8.6 $\mathrm{mol} \cdot \mathrm{m}^{-2} \cdot \mathrm{d}^{-1}$, node number of $K$. manginii, $K$. nyikae, and $K$. rotundifolia decreased by 1.6, 1.4, and 0.9 nodes, respectively, whereas the node number of $K$. glaucescens decreased by 1.1 nodes as the DLI increased to 17.2 $\mathrm{mol} \cdot \mathrm{m}^{-2} \cdot \mathrm{d}^{-1}$ (Table $\left.\mathrm{l}\right)$. There was no effect of DLI on the node number below the terminal inflorescence of $K$. lacinitata and $K$. velutina (Table 1 ).

The effect of DLI on the time to first open flower affected species differently (Table 2). The time to first open flower of K. laciniata, K. manginii, and $K$. velutina decreased by 12 , 11 , and $14 \mathrm{~d}$, respectively, as DLI increased from 4.3 to $17.2 \mathrm{~mol} \cdot \mathrm{m}^{-2} \cdot \mathrm{d}^{-1}$ (Table 2). Alternatively, the time to first open flower for $K$. glaucescens, $K$. nyikae, and $K$. rotundifolia was unaffected by DLI (Table 2).

Total flowers increased as DLI increased for all kalanchoe species; however, the rate of increase varied with species (Table 3 ). The total flowers of $K$. laciniata and $K$. nyikae increased by 17 and 42 flowers, respectively, as the DLI increased from 4.3 to 8.6 $\mathrm{mol} \cdot \mathrm{m}^{-2} \cdot \mathrm{d}^{-1}$ (Table 3 ). As DLI increased from 4.3 to $17.2 \mathrm{~mol} \cdot \mathrm{m}^{-2} \cdot \mathrm{d}^{-1}$, the total flowers of $K$. glaucescens, $K$. manginii, K. rotundifolia, and $K$. velutina increased by $41,25,62$, and 73 flowers, respectively (Table 3 ). 
Table 2. Effect of daily light integral (DLI) on time to first open flower of six kalanchoe species.

\begin{tabular}{lccc}
\hline & \multicolumn{3}{c}{ Time to first open flower $(\mathbf{d})$} \\
\cline { 2 - 4 } Species & \multicolumn{3}{c}{ DLI $\left(\mathbf{m o l} \cdot \mathbf{m}^{-\mathbf{2}} \cdot \mathbf{d}^{-\mathbf{1}}\right)$} \\
\cline { 2 - 4 } Kalanchoe glaucescens & $72 \mathrm{a}^{\mathrm{z}} \mathrm{A}^{\mathrm{y}}$ & $70 \mathrm{aA}$ & $\mathbf{1 7 . 2}$ \\
K. laciniata & $00 \mathrm{bC}$ & $91 \mathrm{abC}$ & $69 \mathrm{aAB}$ \\
K. manginii & $90 \mathrm{cB}$ & $83 \mathrm{bB}$ & $79 \mathrm{aC}$ \\
K. nyikae & $90 \mathrm{aB}$ & $89 \mathrm{aC}$ & $86 \mathrm{aD}$ \\
K. rotundifolia & $67 \mathrm{aA}$ & $67 \mathrm{aA}$ & $66 \mathrm{aA}$ \\
K. velutina & $90 \mathrm{cB}$ & $82 \mathrm{bB}$ & $76 \mathrm{aBC}$ \\
Species (S) & $* * *$ & & \\
DLI (D) & $* * *$ & & \\
S $\times$ D & $*$ & & \\
\hline
\end{tabular}

${ }^{2}$ Lowercase letters indicate mean separation within a species across DLIs by Tukey's honestly significant difference (HSD) test at $P \leq 0.05$.

${ }^{y}$ Uppercase letters indicate mean separation within a DLI across species by Tukey's HSD at $P=0.05$. $*, * *$ Significant at $P \leq 0.05$ or 0.001 , respectively.

Table 3. Effect of daily light integral (DLI) on total flowers of six kalanchoe species.

\begin{tabular}{lccc}
\hline & \multicolumn{3}{c}{ Total flowers (no.) } \\
\cline { 2 - 4 } Species & \multicolumn{3}{c}{ DLI $\left(\mathbf{m o l} \cdot \mathbf{m}^{-\mathbf{2}} \cdot \mathbf{d}^{-\mathbf{1}}\right)$} \\
\cline { 2 - 4 } Kalanchoe glaucescens & $\mathbf{4 . 3}$ & $\mathbf{8 . 6}$ & $\mathbf{1 7 . 2}$ \\
K. laciniata & $26 \mathrm{aA} \mathrm{A}^{\mathrm{y}}$ & $43 \mathrm{aAB}$ & $58 \mathrm{bAB}$ \\
K. manginii & $18 \mathrm{aA}$ & $53 \mathrm{bB}$ & $58 \mathrm{bAB}$ \\
K. nyikae & $60 \mathrm{aB}$ & $27 \mathrm{aA}$ & $43 \mathrm{bA}$ \\
K. rotundifolia & $25 \mathrm{aA}$ & $102 \mathrm{bC}$ & $86 \mathrm{bB}$ \\
K. velutina & $54 \mathrm{aB}$ & $50 \mathrm{bAB}$ & $87 \mathrm{cB}$ \\
Species $(S)$ & $* * *$ & $111 \mathrm{bC}$ & $127 \mathrm{bC}$ \\
DLI $(\mathrm{D})$ & $* * *$ & & \\
S $\times \mathrm{D}$ & $* * *$ & & \\
\hline
\end{tabular}

${ }^{2}$ Lowercase letters indicate mean separation within a species across DLIs by Tukey's honestly significant difference (HSD) test at $P \leq 0.05$.

'Uppercase letters indicate mean separation within a DLI across species by Tukey's HSD at $P=0.05$. $* * *$ Significant at $P \leq 0.001$.

Species and DLI interacted to affect shoot height (Table 4). Shoot height of $K$. glaucescens and $K$. rotundifolia increased to $7 \mathrm{~cm}$ as DLI increased from 4.3 to $17.2 \mathrm{~mol} \cdot \mathrm{m}^{-2} \cdot \mathrm{d}^{-1}$ (Table 4). Alternatively, as DLI increased from 4.3 to $17.2 \mathrm{~mol} \cdot \mathrm{m}^{-2} \cdot \mathrm{d}^{-1}$, shoot height of $K$. nyikae decreased to $21 \mathrm{~cm}$ (Table 4$)$. The DLI had no significant effect on shoot heights of $K$. laciniata, $K$. manginii, and $K$. velutina (Table 4 ).

Dry weight gain increased for all species as DLI increased above 4.3 $\mathrm{mol} \cdot \mathrm{m}^{-2} \cdot \mathrm{d}^{-1}$ (Table 5 ). Dry weight gain of $K$.glanescens increased by $2.3 \mathrm{mg} \cdot \mathrm{d}^{-1}$ as DLI increased from 4.3 to 8.6 $\mathrm{mol} \cdot \mathrm{m}^{-2} \cdot \mathrm{d}^{-1}$, but did not increase significantly as DLI increased more to $17.2 \mathrm{~mol} \cdot \mathrm{m}^{-2} \cdot \mathrm{d}^{-1}$ (Table 5 ). In contrast, as DLI increased from 4.3 to $17.2 \mathrm{~mol} \cdot \mathrm{m}^{-2} \cdot \mathrm{d}^{-1}$, dry weight gain of $K$. laciniata, K. manginii, K. nyikae,
$K$. rotundifolia, $K$. velutina increased by $10.5,4.6,7.4,8.5$, and 21.1 $\mathrm{mg} \cdot \mathrm{d}^{-1}$, respectively (Table 5 ).

\section{Discussion}

Our results are in agreement with the previous reports on the effect of DLI or supplemental light on other potted and bedding plants (Carvalho et al., 2006; Erwin and Warner, 2002; Faust et al., 2005; Giselrod et al., 1989; Mattson and Erwin, 2005; Oh et al., 2009; Warner and Erwin, 2003, 2005; Zimmer, 1985). Irradiance responses of kalanchoe species were identified according to Erwin and Warner (2002) and Mattson and Erwin (2005): a reduced node number below the inflorescence in response to increasing DLI is defined as a facultative irradiance (FI) response and no reduction in node number below the inflorescence in response to increasing
DLI is defined as an irradiance indifferent (II) response. Therefore, we classify $K$. glaucescens, $K$. manginii, $K$. nyikae, and $K$. rotundifolia as having a FI response with respect to the range of DLIs used in this study. Alternatively, $K$. laciniata and $K$. velutina may be classified as having an II response here. Similar variation in irradiance responses within a genus have been reported before (Warner and Erwin, 2003). Warner and Erwin (2003) reported that the node number of rosa del río $(\mathrm{Hi}$ biscus cisplatanus) below the first flower decreased from 26 to 18 nodes as the DLI increased from 8.3 to 25.5 $\mathrm{mol} \cdot \mathrm{m}^{-2} \cdot \mathrm{d}^{-1}$ (FI response), whereas the node number of swamp rosemallow (Hibiscus moscheotus) was unaffected by DLI when plants were grown under a 16-h photoperiod (II response).

The different effects of DLI on the time to first open flower have been reported for several other potted plants (Carvalho et al., 2006; Giselrod et al., 1989; Oh et al., 2009; Warner and Erwin, 2003). A reduction in the time to first open flower by $58 \mathrm{~d}$ was reported for 'Metis Scarlet Red' cyclamen as the DLI increased from 1.4 to 17.3 $\mathrm{mol} \cdot \mathrm{m}^{-2} \cdot \mathrm{d}^{-1}$ (Oh et al., 2009). Carvalho et al. (2006) reported a $12 \mathrm{~d}$ reduction in the time to first open flower of 'Anatole' kalanchoe (K. blossfeldiana) as the DLI increased from 2.1 to 7.2 $\mathrm{mol} \cdot \mathrm{m}^{-2} \cdot \mathrm{d}^{-1}$. Alternatively, increasing supplemental irradiance from 14 to 70 $\mu \mathrm{mol} \cdot \mathrm{m}^{-2} \cdot \mathrm{s}^{-1}$ did not affect the time to first open flower of 'Pollux' kalanchoe (Giselrod et al., 1989). Warner and Erwin (2003) reported that the time to first open flower of monarch rosemallow ( $H$. radiatus) was unaffected by DLI under a 9-h photoperiod, whereas increasing the DLI from 9.5 to $16.4 \mathrm{~mol} \cdot \mathrm{m}^{-2} \cdot \mathrm{d}^{-1}$ the days to first open flower of flower-of-an-hour $(H$. trionum) decreased from 96 to $57 \mathrm{~d}$.

Our data on the effect of the DLI on total flowers (Table 3 ) are consistent with other studies (Faust et al., 2005; Oh et al., 2009; Warner and Erwin, 2005; Zimmer, 1985). For example, Zimmer (1985) reported total flowers on $K$. porphyrocalyx increased from 59 to 154 flowers as the DLI increased from 1.2 to $2.6 \mathrm{~mol} \cdot \mathrm{m}^{-2} \cdot \mathrm{d}^{-1}$. Total flowers of 'Vodka Cocktail' begonia (Begonia $\times$ semperflorens-cultorum), 'Pacific Lilac' vinca (Catharanthus roseus), 'Apple Blossom' petunia (Petunia $\times$ hybrida), and 'Dreamland Rose' zinnia (Zinnia elegans) increased as DLI increased from 5 
Table 4. Effect of daily light integral (DLI) on shoot height of six kalanchoe species.

\begin{tabular}{lccc}
\hline & \multicolumn{3}{c}{ Shoot ht $(\mathbf{c m})^{\mathbf{z}}$} \\
\cline { 2 - 4 } Species & \multicolumn{3}{c}{$\mathbf{D L I}\left(\mathbf{m o l} \cdot \mathbf{m}^{-\mathbf{2}} \cdot \mathbf{d}^{-\mathbf{l}}\right)$} \\
\cline { 2 - 4 } Kalanchoe glaucescens & $9 \mathrm{a}^{\mathrm{y}} \mathrm{A}^{\mathrm{x}}$ & $\mathbf{8 . 6}$ & $\mathbf{1 7 . 2}$ \\
K. laciniata & $25 \mathrm{aCD}$ & $28 \mathrm{bB}$ & $14 \mathrm{bA}$ \\
K. manginii & $18 \mathrm{aBC}$ & $17 \mathrm{aA}$ & $27 \mathrm{aBC}$ \\
K. nyikae & $52 \mathrm{cE}$ & $42 \mathrm{bC}$ & $\mathbf{1 6 \mathrm { A }}$ \\
K. rotundifolia & $14 \mathrm{aAB}$ & $21 \mathrm{bA}$ & $23 \mathrm{bB}$ \\
K. velutina & $32 \mathrm{aD}$ & $35 \mathrm{aB}$ & $35 \mathrm{aD}$ \\
Species $(S)$ & $* * *$ & & \\
DLI $(\mathrm{D})$ & $*$ & & \\
S $\times \mathrm{D}$ & $* * *$ & & \\
\hline
\end{tabular}

${ }^{\mathrm{z}} 1 \mathrm{~cm}=0.3937$ inch.

'Lowercase letters indicate mean separation within a species across DLIs by Tukey's honestly significant difference (HSD) test at $P \leq 0.05$.

${ }^{x}$ Uppercase letters indicate mean separation within a DLI across species by Tukey's HSD at $P=0.05$

$*{ }^{* * *}$ Significant at $P \leq 0.05$ or 0.001 , respectively.

Table 5. Effect of daily light integral (DLI) on dry weight gain on six kalanchoe species.

\begin{tabular}{lccr}
\hline & \multicolumn{3}{c}{ Dry wt gain $\left(\mathbf{m g} \cdot \mathbf{d}^{-\mathbf{1}}\right)^{\mathbf{z}}$} \\
\cline { 2 - 4 } Species & \multicolumn{3}{c}{ DLI $\left(\mathbf{m o l} \cdot \mathbf{m}^{-2} \cdot \mathbf{d}^{-\mathbf{1}}\right)$} \\
\cline { 2 - 4 } Kalanchoe glaucescens & $1.2 \mathrm{a}^{\mathrm{y}} \mathrm{A}^{\mathrm{x}}$ & $\mathbf{8 . 6}$ & $\mathbf{1 7 . 2}$ \\
K. laciniata & $10.7 \mathrm{aB}$ & $19.5 \mathrm{bA} \mathrm{abB}$ & $5.1 \mathrm{bA}$ \\
K. manginii & $4.2 \mathrm{aA}$ & $6.2 \mathrm{aA}$ & $21.2 \mathrm{bB}$ \\
K. nyikae & $20.9 \mathrm{aC}$ & $32.2 \mathrm{abC}$ & $8.8 \mathrm{bA}$ \\
K. rotundifolia & $2.6 \mathrm{aA}$ & $6.7 \mathrm{bA}$ & $28.3 \mathrm{bBC}$ \\
K. pelutina & $10.5 \mathrm{aB}$ & $20.3 \mathrm{bB}$ & $31.1 \mathrm{cA}$ \\
Species (S) & $* * *$ & & $\mathrm{cC}$ \\
DLI (D) & $* * *$ & & \\
S $\times \mathrm{D}$ & $* * *$ & & \\
\hline
\end{tabular}

${ }^{\mathrm{z}} 1 \mathrm{mg}=3.5274 \times 10^{-5} \mathrm{oz}$.

y Lowercase letters indicate mean separation within a species across DLIs by Tukey's honestly significant difference (HSD) test at $P \leq 0.05$.

${ }^{x}$ Uppercase letters indicate mean separation within a DLI across species by Tukey's HSD at $P=0.05$. *** Significant at $P \leq 0.001$.

to $43 \mathrm{~mol} \cdot \mathrm{m}^{-2} \cdot \mathrm{d}^{-1}$ (Faust et al., 2005). Similarly, as DLI increased from 10.5 to $17.5 \mathrm{~mol} \cdot \mathrm{m}^{-2} \cdot \mathrm{d}^{-1}$, the flower bud number of 'Rocket Rose' snapdragon ( $A n$ tirrhinum majus), 'Super Elfin White' impatiens (Impatiens walleriana), 'Mystic Yellow' mimulus (Mimulus $\times$ bybridus), and 'Clown Burgundy' torenia (Torenia fournieri) increased (Warner and Erwin, 2005).

The increase in shoot height for $K$. glaucescens and $K$. rotundifolia agrees with the reports of increasing DLI and supplemental light for other kalanchoe cultivars (Carvalho et al., 2006; Giselrod et al., 1989). Height of 'Anatole' kalanchoe increased by $12 \%$ as DLI increased from 2.1 to 7.2 $\mathrm{mol} \cdot \mathrm{m}^{-2} \cdot \mathrm{d}^{-1}$ (Carvalho et al., 2006). Giselrod et al. (1989) reported that height of 'Pollux' kalanchoe increased from 5.65 to $7.73 \mathrm{~cm}$ as supplemental lighting increased from 14 to 70 $\mu \mathrm{mol} \cdot \mathrm{m}^{-2} \cdot \mathrm{s}^{-1}$. As discussed earlier, the flower number of kalanchoe species increases when plants are grown under higher DLIs or light intensities. This increase in flower number causes the reproductive portion of stems to be taller, contributing to the increase in total plant height (data not shown).

Increasing the DLI or supplemental light frequently increases biomass accumulation (Giselrod et al., 1989; Oh et al., 2009; Warner and Erwin, 2005). The shoot dry matter increased by $5.6 \%$ for 'Pollux' kalanchoe as supplemental light intensity increased from 14 to $70 \mu \mathrm{mol} \cdot \mathrm{m}^{-2} \cdot \mathrm{s}^{-1}$ (Giselrod et al., 1989). Similarly, dry weight gain of 'Calypso Orange' calendula (Calendula officinalis), 'Super Elfin White' impatiens, and 'Clown
Burgundy' torenia increased as the DLI increased from 10.5 to 21.8 $\mathrm{mol} \cdot \mathrm{m}^{-2} \cdot \mathrm{d}^{-1}$ (Warner and Erwin, 2005 ). However, as observed in this experiment with $K$. glaucescens, increases in dry weight gain in response to increasing DLI may reach a point of saturation (Oh et al., 2009; Warner and Erwin, 2005). For example, increasing the DLI from 10.5 to 17.5 $\mathrm{mol} \cdot \mathrm{m}^{-2} \cdot \mathrm{d}^{-1}$ increased dry weight gain of 'Rocket Rose' snapdragon and 'Mystic Yellow' mimulus, whereas further increase in the DLI from 17.5 to $21.8 \mathrm{~mol} \cdot \mathrm{m}^{-2} \cdot \mathrm{d}^{-1}$ did not increase dry weight gain further (Warner and Erwin, 2005). Similarly, dry weight of 'Metis Scarlet Red' cyclamen after 16 weeks increased as the DLI increased from 1.4 to $\approx 11.5 \mathrm{~mol} \cdot \mathrm{m}^{-2} \cdot \mathrm{d}^{-1}$, whereas further increasing the DLI to $17.3 \mathrm{~mol} \cdot \mathrm{m}^{-2} \cdot \mathrm{d}^{-1}$ did not increase the dry weight (Oh et al., 2009).

\section{Conclusions}

We present data here that, in addition to classifying the irradiance response groups, will allow producers to produce high-quality flowering $K$. glaucescens, K. laciniata, K. manginii, $K$. nyikae, $K$. uniflora, and $K$. velutina plants. In general, increasing the DLI from 4.3 to 8.6 or $17.2 \mathrm{~mol} \cdot \mathrm{m}^{-2} \cdot \mathrm{d}^{-1}$ will reduce the time to first open flower while increasing total flowers and shoot dry weight. Though an increase in plant height with increasing DLI was observed for some species, the benefit of reduced production time and increased ornamental value may be an acceptable trade-off. Chemical plant growth retardants may be applied to suppress an increase in plant height in response to higher DLIs, as numerous plant growth retardants successfully suppress stem elongation of several of these species (Currey, 2009).

\section{Literature cited}

Carvalho, S.M.P., S.E. Wuillai, and E. Heuvelink. 2006. Combined effects of light and temperature on product quality of Kalanchoe blossfeldiana. Acta Hort. 711:121-126.

Currey, C.J. 2009. Factors affecting flowering and growth in the genus Kalanchoe. Univ. of Minnesota, Saint Paul, M.S. thesis.

Descoings, B. 2005. Kalanchoe, p. 143181. In: E. Eggli (ed.). Illustrated handbook of succulent plants: Crassulaceae. Springer, Berlin, Germany. 
Dole, J.M. and H.F. Wilkins. 2005. Floriculture: Principles and species. Prentice Hall, Upper Saddle River, NJ.

Erwin, J.E. and R.M. Warner. 2002. Determination of photoperiodic response group and effect of supplemental irradiance on flowering of several bedding plant species. Acta Hort. 580:95-100.

Fausey, B.A., R.D. Heins, and A.C. Cameron. 2005. Daily light integral affects flowering and quality of greenhousegrown Achillea, Gaura, and Lavandula. HortScience 40:114-118.

Faust, J.E. 2003. Light, p. 71-84. In: D. Hamrick (ed.). Ball redbook, 17th ed. Vol 2: Crop production. Ball Publishing, Batavia, IL.

Faust, J.E., V. Holcombe, N.C. Rajapakse, and D.R. Layne. 2005. The effect of daily light integral on bedding plant growth and flowering. HortScience 40:645-649.

Garland, K.F., S.E. Burnett, L.B. Stack, and D. Zhang. 2010. Minimum daily light integral for growing high-quality coleus. HortTechnology 20:929-933.

Giselrod, H.R., I.M. Eidsten, and L.M. Mortenson. 1989. The interaction of daily lighting period and light intensity on growth of some greenhouse plants. Sci. Hort. 38:295-304.

Hamrick, D. 2003. Ball redbook, 17th ed. Vol. 2: Crop production. Ball Publishing, Batavia, IL.

Hanan, J.J. 1998. Greenhouses: Advanced technology for protected horticulture. CRC Press, Boca Raton, FL.

Korczynski, P.M., J. Logan, and J.E. Faust. 2002. Mapping monthly distribution of daily light integrals across the contiguous United States. HortTechnology 12:12-16.

Lambers, H., F.S. Chapin, III, and T.J. Pons. 2008. Plant physiological ecology. 2nd ed. Springer, New York, NY.

Larcher, W. 2003. Physiological plant ecology: Ecophysiology and stress physiology of functional groups. 4th ed. Springer-Verlag, Berlin, Germany.

Mattson, N.S. and J.E. Erwin. 2005. The impact of photoperiod and irradiance on flowering of several herbaceous ornamentals. Sci. Hort. 104:275-292.
Oh, W., I.H. Cheon, K.S. Kim, and E.S. Runkle. 2009. Photosynthetic daily light integral influences flowering time and crop characteristics of Cyclamen persicum. HortScience 44:341-344.

Roh, M.S. and R.H. Lawson. 1998. Requirements for new floral crops-Perspectives for the United States of America. Acta Hort. 454:29-38.

Warner, R.M. and J.E. Erwin. 2003. Effect of photoperiod and daily light integral on flowering of five Hibiscus sp. Sci. Hort. 97:341-351.

Warner, R.M. and J.E. Erwin. 2005. Prolonged high temperature exposure and daily light integral impact growth and flowering of five herbaceous ornamental species. J. Amer. Soc. Hort. Sci. 130: 319-325.

Wilkins, H.F. and J.E. Erwin. 1998. Necessary considerations to introduce a new taxa. Acta Hort. 454:81-83.

Zimmer, K. 1985. Kalanchoe porphyrocalyx, p. 236-239. In: A.H. Halevy (ed.). Handbook of flowering, Vol. 3. CRC Press, Boca Raton, FL. 